Commentary

\title{
Moving on: Is Existenzminimum Still Relevant?
}

\author{
Bruno Marchand \\ Laboratoire de Théorie et Histoire 2, École Polytechnique Fédérale de Lausanne, 1015 Lausanne, Switzerland; \\ E-Mail: bruno.marchand@epfl.ch
}

Submitted: 9 September 2019 | Accepted: 9 September 2019 | Published: 30 September 2019

\begin{abstract}
In the inter-war period, progressive architects confronted the building of mass housing with an analogy with rational and functional workplaces. At the 2nd CIAM (Congrès Internationaux d'Architecture Moderne), held in Frankfurt in 1929, this was tested against the formulation of space standards for a vital minimum, in order to increase the quantity of housing and reduce construction costs. This approach presumed the search for optimal living conditions and hygiene. The analogy with the world of work is particularly striking in the case of design of kitchens, removable furniture and storage spaces to maximize the use of space. In rational-and above all minimum-housing, the size of the rooms mainly depends on the size of the furniture. In this perspective, today in Switzerland new housing projects face the same issues, caused by a housing shortage that has plagued the country in the last decades. This suggests that Existenzminimum is still current for contemporary design.
\end{abstract}

\section{Keywords}

Existenzminimum; rational housing; removable furniture; Switzerland

\section{Issue}

This commentary is part of the issue "Housing Builds Cities", edited by Luca Ortelli (École Polytechnique Fédérale de Lausanne, Switzerland), Chiara Monterumisi (École Polytechnique Fédérale de Lausanne, Switzerland) and Alessandro Porotto (École Polytechnique Fédérale de Lausanne, Switzerland).

(C) 2019 by the author; licensee Cogitatio (Lisbon, Portugal). This article is licensed under a Creative Commons Attribution 4.0 International License (CC BY).

\section{Introduction}

In the 1951 movie An American in Paris, the American actor Gene Kelly plays Jerry Mulligan, a young romantic artist who supposedly lives in Montmartre in a very small apartment, practically a single room at the top of a building. The opening scene of the movie highlights Kelly's dancing skills as, barely awake, he prepares breakfast with synchronized and elegant gestures (Figure 1).

Let's visualize the scene:

Someone knocks on the door. The person sleeping wakes up, opens the door ajar from his bed and takes a small paper bag containing croissants through the narrow opening. Then he gets up, lifts the bed up to the ceiling with the help of ropes, opens the wardrobe pulling out a table and chair, looks for a cup and a knife in a drawer with his left hand while taking his jacket from the wardrobe with his right hand, closes the drawer with his knee and turns towards the table. That's it, that's it, breakfast is served. (Muller, 2005, p. 79; Franzinetti's translation)

\section{Dancing and Taylorism}

The movie was directed by Vincente Minnelli and Gene Kelly was the choreographer: Kelly used the theme of minimum space and its habitability, transforming everyday domestic tasks into a continuous flow of synchronized movements. It is interesting to compare Kelly's movements to the repetitive and synchronized gestures designed by Frederick Winslow Taylor. This parallel between dance and Taylorism has a famous precedent: the ballets of the Die Rosy girls in Berlin (Figure 2), whose synchronized movements were reminiscent of the factory assembly lines.

It is not only the ballets of Gene Kelly and the Die Rosy girls that echo the effectiveness and aesthetics of 


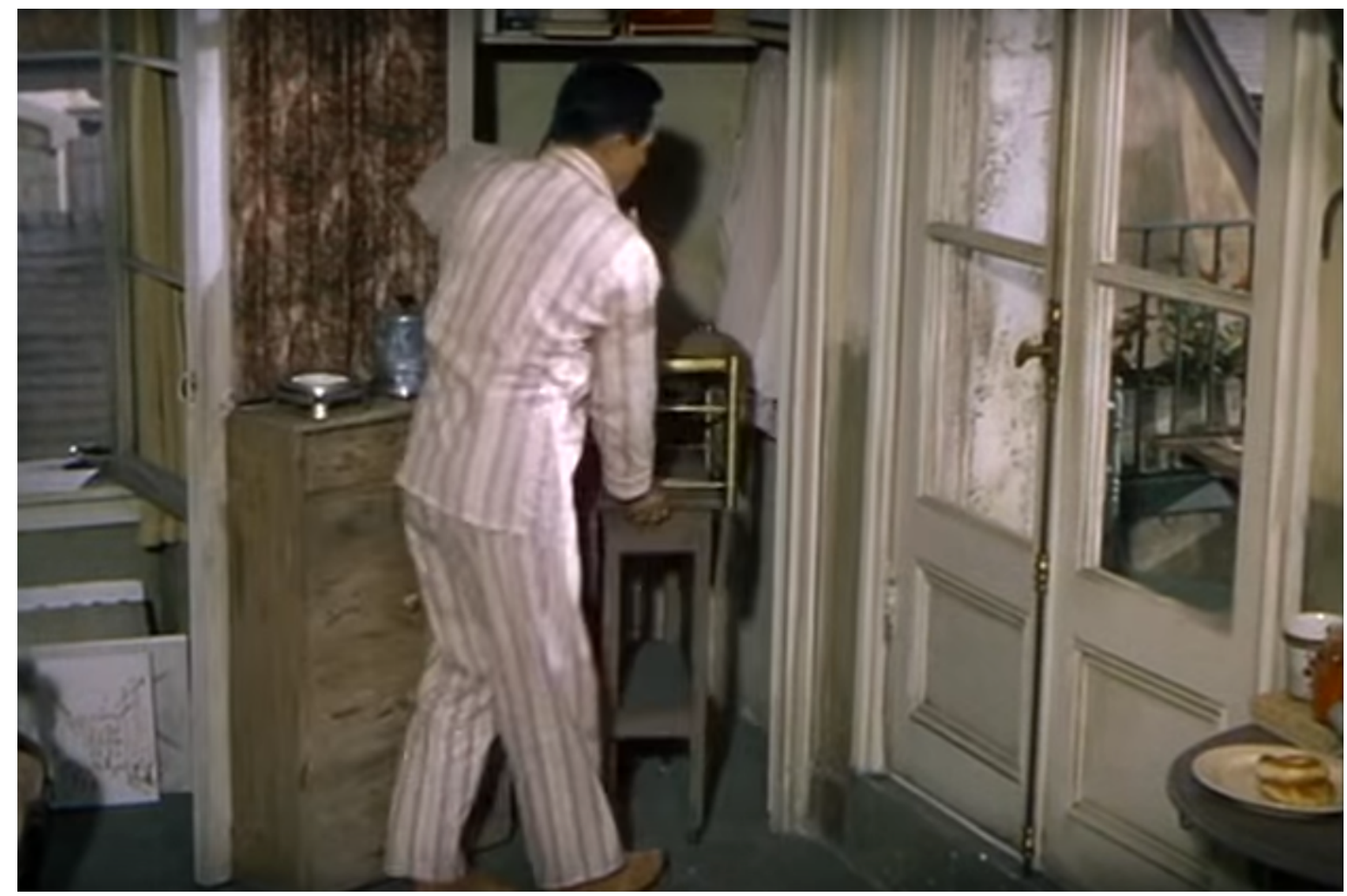

Figure 1. Gene Kelly, a scene from Vincente Minnelli's movie An American in Paris (1951). Source: Freed and Minnelli (1951).

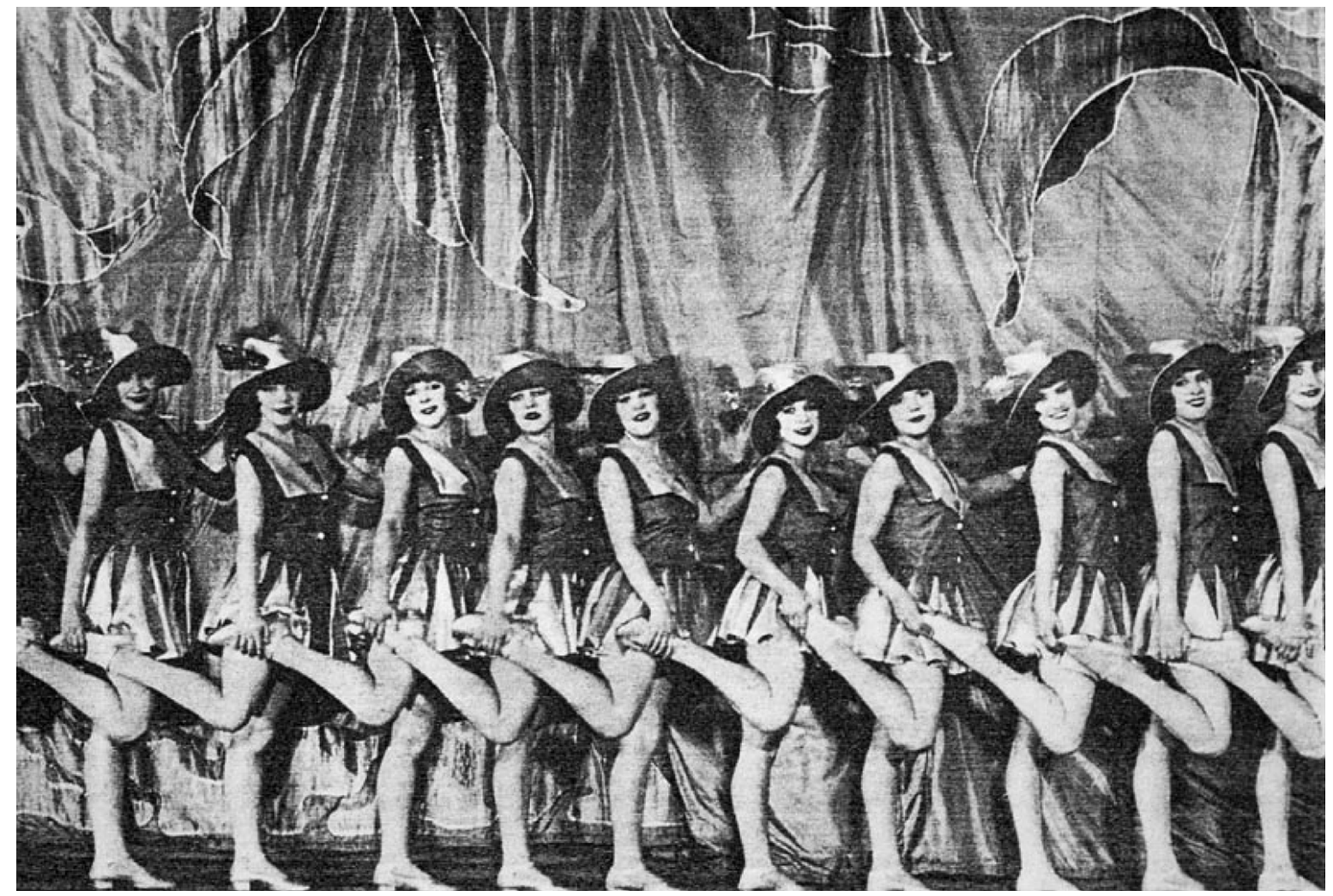

Figure 2. Die Rosy girls in Berlin. Source: Murard and Zylberman (1978, p. 385). 
Taylorism. In the inter-war period, progressive architects also confronted the building of mass housing with an astonishing analogy with rational and functional workplaces. According to the Viennese architect Margarete Schütte-Lihotzky (1927), "We transpose the economic principles of the work of labour and company management, into the organisation of domestic work, which when applied to factories and clerical work lead to an unsuspected increase in efficiency" (Schütte-Lihotzky, 1927, pp. 120-121; Franzinetti's translation).

At the 2nd CIAM (Congrès Internationaux d'Architecture Moderne), held in Frankfurt in 1929, this was tested against the space standards for the vital minimum of living, an approach whose objective was to increase the quantity of housing and reduce construction costs. However, minimum housing presumes the search for optimal living conditions and hygiene (Figures 3 and 4). For Walter Gropius, the problem of minimum apartmentMinimalwohnung-consists of defining the "minimum of space, air, light and heat, necessary for men to develop their own vital functions without restrictions due to lodging, namely a minimum modus vivendi, instead of amodus non moriendi" (Gropius, 1995, p. 77; Franzinetti's translation).

\section{Breaking down Movements and 'Routing'}

The analogy with the world of work is particularly striking in the case of design of kitchens. Architects were focused on them with a view to switching from the Wohnküchethe large farm kitchen big enough to eat-to a working kitchen, at the side of the living or dining room too small to eat meals there. But how could kitchen appliances be organised to reduce housewives' burden?

The irrational nature of domestic work was at the heart of Christine Frederick's research. She was an American feminist who published in 1915 a book on the subject entitled Household Engineering: Scientific Management in the Home. As this title indicates, Frederick advocates the application of the principles of work rationalization set out by Taylor to the organisation of the house, and specifically to households without servants. She focused in particular on the layout of household appliances and equipment in the kitchen, which she analysed, comparing a "good" to a "bad" example, using a picture to illustrate routing (Frederick, 1915).

The method broke down the range of movements when preparing meals inside a kitchen and thus proved that the rational and linear layout of the appliances and equipment made it possible to identify and subsequently shorten the routes to save energy. Christine Frederick's book was translated into German in 1922 and quickly became a source of inspiration for German architects, who transposed her routing method to the organisation of domestic spaces. Berlin architect Bruno Taut was the first to adopt the comparative method between a "good" and a "bad" housing plan, analysed according to the relationships between the rooms and routing.

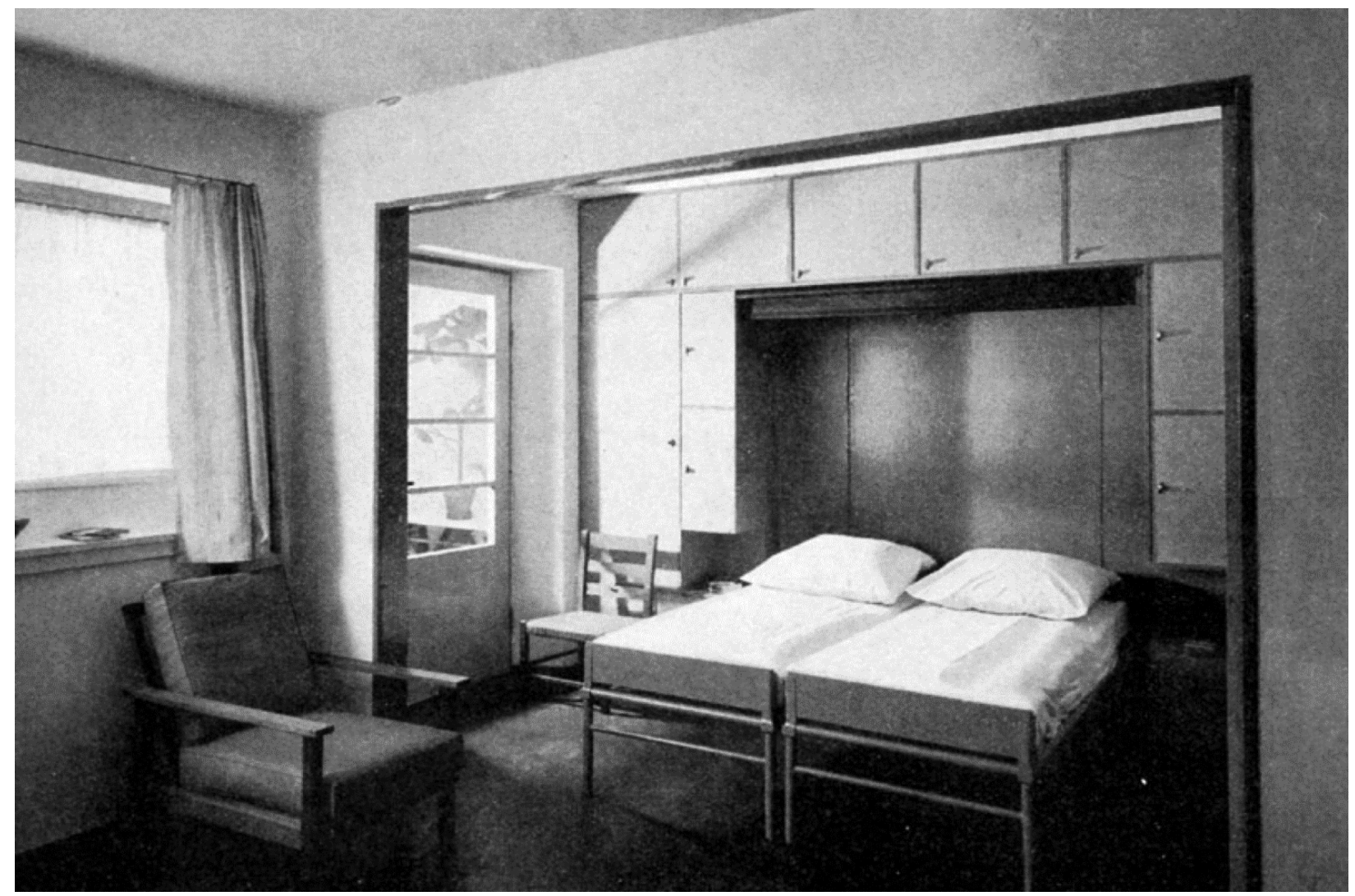

Figure 3. Ferdinand Kramer, housing in Frankfurt, beds in position in the living room. Source: Borngraeber (1978, p. 377). 

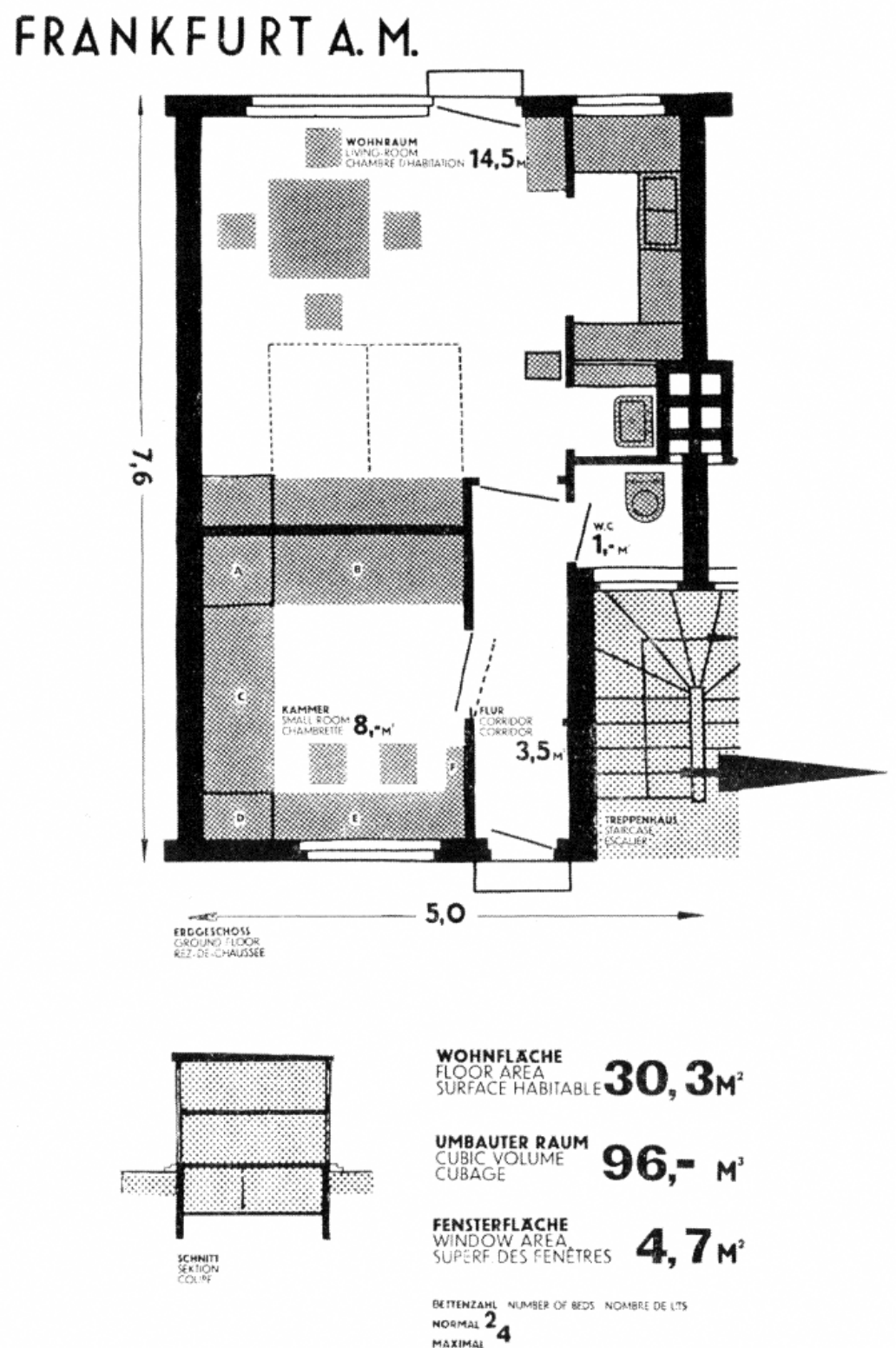

Figure 4. Dwelling type exhibited at the 2nd CIAM in Frankfurt with the foldable bed indicated with dashed lines. Source: Quiring, Voigt, Cachola Schmal, and Herrel (2011).

The housing plan proposed by Taut (1924) in his book Die neue Wohnung: Die Frau als Schöpferin, dedicated to women, was to become a kind of ideal cell, bringing together both the principle of routing economics and the hygiene principles linked to sunlight. Accommodation was organised around a collective and an intimate sphere commonly (and reductively) called "day" and "night" zones, their positions being dictated by the course of the sun: The rooms to the east benefited from the morning sun, while the living room and the kitchen, to the west, were positioned to catch the evening rays.

The collective and intimate spheres of dwellings were distinct, and the rooms connected by short chains of steps without intersections. In rational housing, every space was used to the best: no more "cold rooms" (kalte Pracht) that were only used on Sundays to receive guests.
Likewise, the various members of the family were separated: the parents' rooms from the children's, the girls' rooms from the boys' rooms. Different activities were not allowed in the same room at the same time.

\section{Removable Furniture}

The opening scene of An American in Paris tends to prove that the mechanization of removable furniture and the logical organization of storage spaces are essential to maximize the use of space. In rational-and above all minimum-housing, the size of the rooms mainly depends on the size of the furniture: As standardized pieces, the dining table, bed or wardrobe become the yardsticks, the basic modules that determine the how domestic spaces are laid out. 
The optimal use of available space also required removable and built-in furniture which, as Ernst May stated, makes it possible to arrange:

The main rooms for two purposes: For instance, the small living room will be transformed into a bedroom by operating a simple handle to make the beds appear or disappear. The tables in the bedroom are all folding; the non-folding children's beds are bunk beds. (May, 1930, p. 8; Franzinetti's translation)

Le Corbusier also asked the same question in a completely different context, that of the Weissenhof in Stuttgart in 1927. In the two-storey (duplex) family house (Figures 5 and 6), each apartment was along a narrow corridor; he imagined occupying the same space during the day and at night thanks to innovative and mobile furniture at the back of the rooms:

In each room a special and economical construction of reinforced cement, making it possible to hide the bed, and providing cabinets calculated exactly to offer each occupant of a unit, a place to hand clothes, the shelves for underwear and bed linen, for hats, shoes, etc...., in short, a complete organization of well shelves to replace all the furniture which usually fill rooms. (Le Corbusier, 1928, p. 13; Franzinetti's translation)
This implementation of the Dom-Ino system is based on a steel pilotis structure and sliding walls which, with the permanent locking joints and "servant spaces", make it possible to organise the same room differently by day and night. Le Corbusier extended the mechanics of a single piece of furniture-the Frankfurt bed-to the housing unit, an analogy to the railway couchette carriage with its minimum compartments connected by a corridor.

Considering that these proposals led to misunderstandings among the exhibition public and to harsh criticism from architects, it could be argued that after all this housing was not for workers but rather for a wealthier tier of the population that accepts to live in this way. Le Corbusier was aware of this situation and reiterated the applications of his flexible interior design system in other projects to prove that Stuttgart's experiment could also be applied to workers' housing.

The first was a project for a rental building, dated 1928-1929, that was never to be built. It consisted of several housing units grouped according to a back-to-back principle around a vertical node bordered by hanging gardens to move. The units were non-through, enclosed at both ends by bathrooms and kitchens. The units had a single open long space which acted as a living room during the day turning into bedrooms at night. Sliding walls were pulled out to make the bedrooms with beds that were stored under the slightly elevated corridor by day.
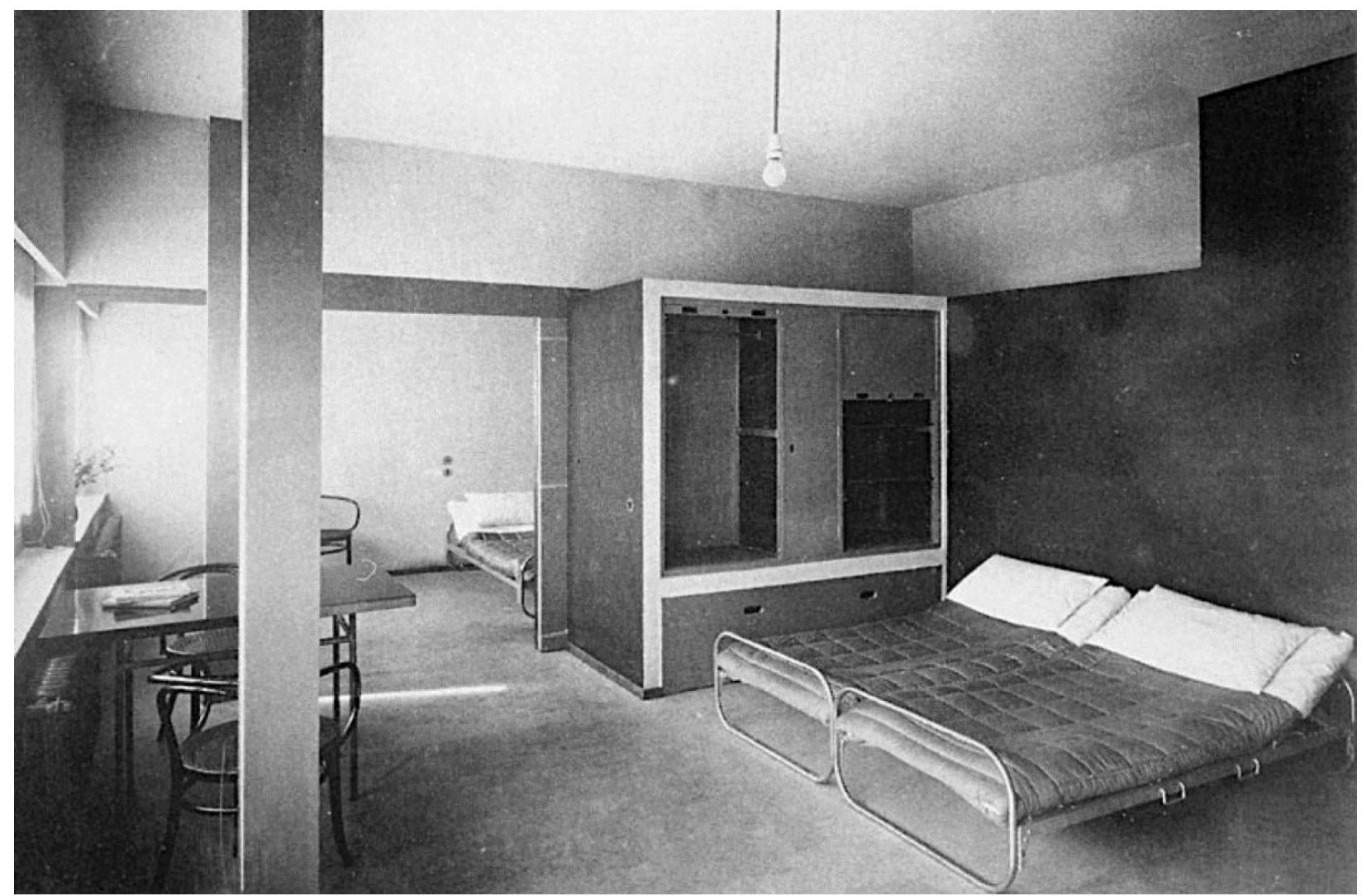

Figure 5. Le Corbusier, two-storey (duplex) housing units at Weissenhof, night layout, 1927. Source: Le Corbusier Pierre Jeanneret (1927, p. 41). Image copyright: (C) FLC/2019, ProLitteris, Zurich. 


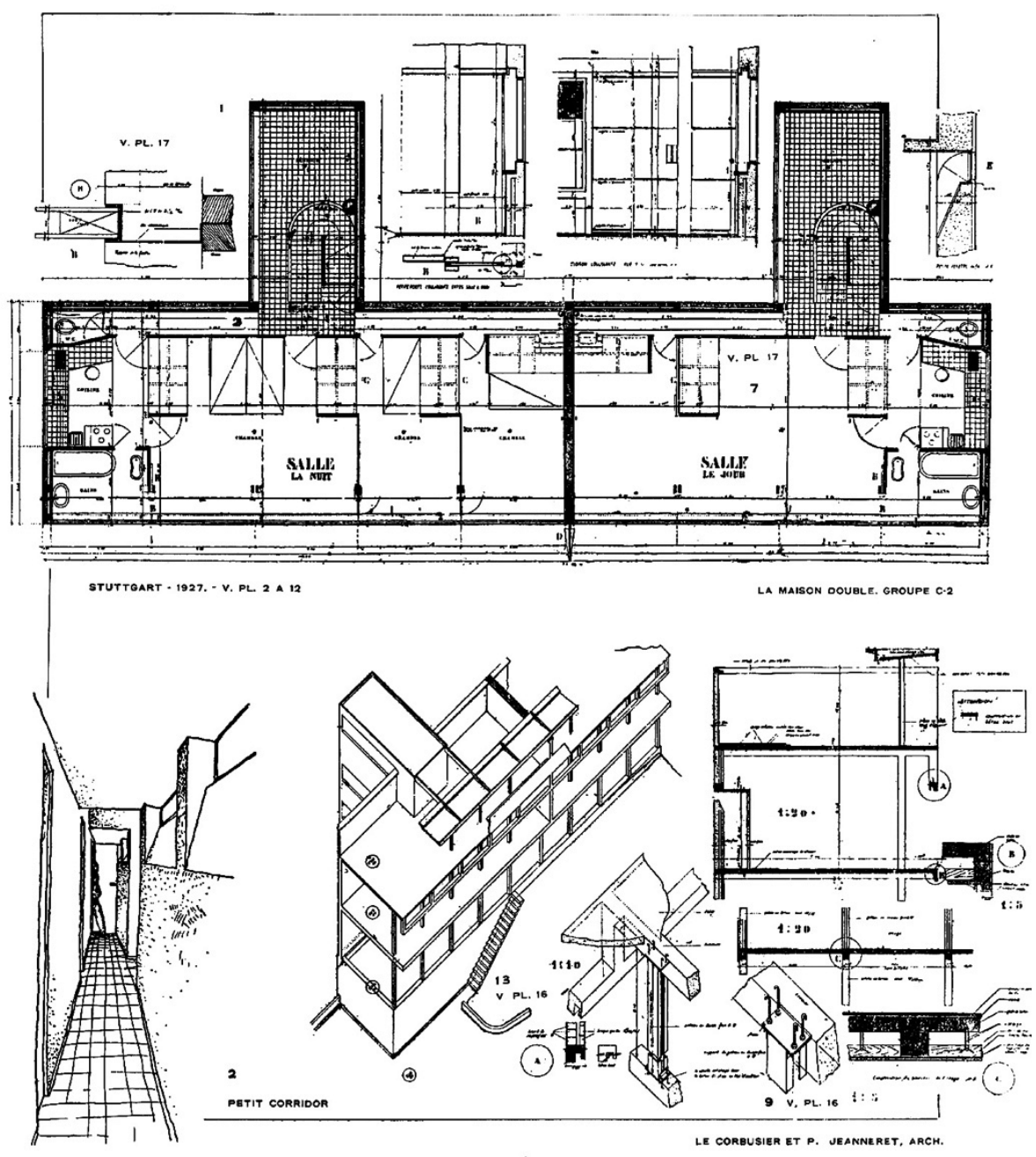

Figure 6. Le Corbusier, two-storey (duplex) housing units at Weissenhof, plan and details, 1927. Source: Le Corbusier (1928). Image copyright: (c) FLC/2019, ProLitteris, Zurich.

According to Le Corbusier, the study of this rental building is "the continuation of the houses made in Stuttgart" (Le Corbusier \& Jeanneret, 1964, p. 184). The Loucheur two-storey units with steel pilotis or pillars and separated by a party or curtain wall made of rubble is also worth mentioning. It was presented in 1929 at the CIAM (Taylor, 1987, p. 239) in Frankfurt, and they too had convertible day-night facilities. Finally, Le Corbusier's obsession with a mechanicistic view of society also led him to design a Maximum Car (Voiture Maximum; Monnier, 1987, p. 52), a minimum prototype, like a Citroën 2 CV where the seats could transform into bunk beds-and become what we can call a "minimum house on wheels" for day and night.

\section{A Century Later: Is Existenzminimum Still Relevant?}

It would be a stretch to compare the problems of the 1920 s and 1930s to the current Swiss collective housing industry. Indeed, almost a century later, the political and economic contexts are quite the opposite: One cannot strictly speak of a crisis situation in Switzerland, but rather of a housing shortage that has plagued the country for decades.

However, we can venture to suggest Existenzminimum is still current in Switzerland, and two recent events stand to prove it: The first concerns the surge in property prices which means that, both in terms of purchase and rental, the middle classes-and the more so workerscan no longer afford to access housing of a certain size and comfort. One of the solutions consists in reducing the dwelling's size, while safeguarding a certain quality, quite a challenge in itself, given that in the past the Swiss, on average, were used to a floor space of 50 sqm per person. The second one is related to changing lifestyles, given more and more people have a "nomadic" lifestyle, where single people or couples have ever shorter housing occupancy periods.

The two above are included in the basic data of the MIN MAX residential and commercial building designGlattpark-in Opfikon, 2013-2016, by EMI Architekten following an invited study contract to competition won in 2013. The compact inner courtyard construction contains collective spaces-such as a laundry room, a com- 
mon kitchen and meeting spaces-arranged around the courtyard, so that the dwelling unit requires a minimum footprint. Units should not be perceived as smaller conventional apartments: The architects sought to make up for the relative compactness of spaces, by increasing the sense of space and creating new architectural features, such as the artist's studios where one can live and work (a nod to Le Corbusier).
The approach is best illustrated in Type MIN 1, with nearly 40 sqm of usable floor space (Figures 7 and 8). In this case, the spatial development is the result of a diagonal view from the entrance to a conservatory and to the high ceiling ( $3 \mathrm{~m}$ in height). The impression of fluid space is further enhanced by interior glass strips above the kitchen and bathroom, which make the ceiling appear as one leaving the room to be considered as a whole.

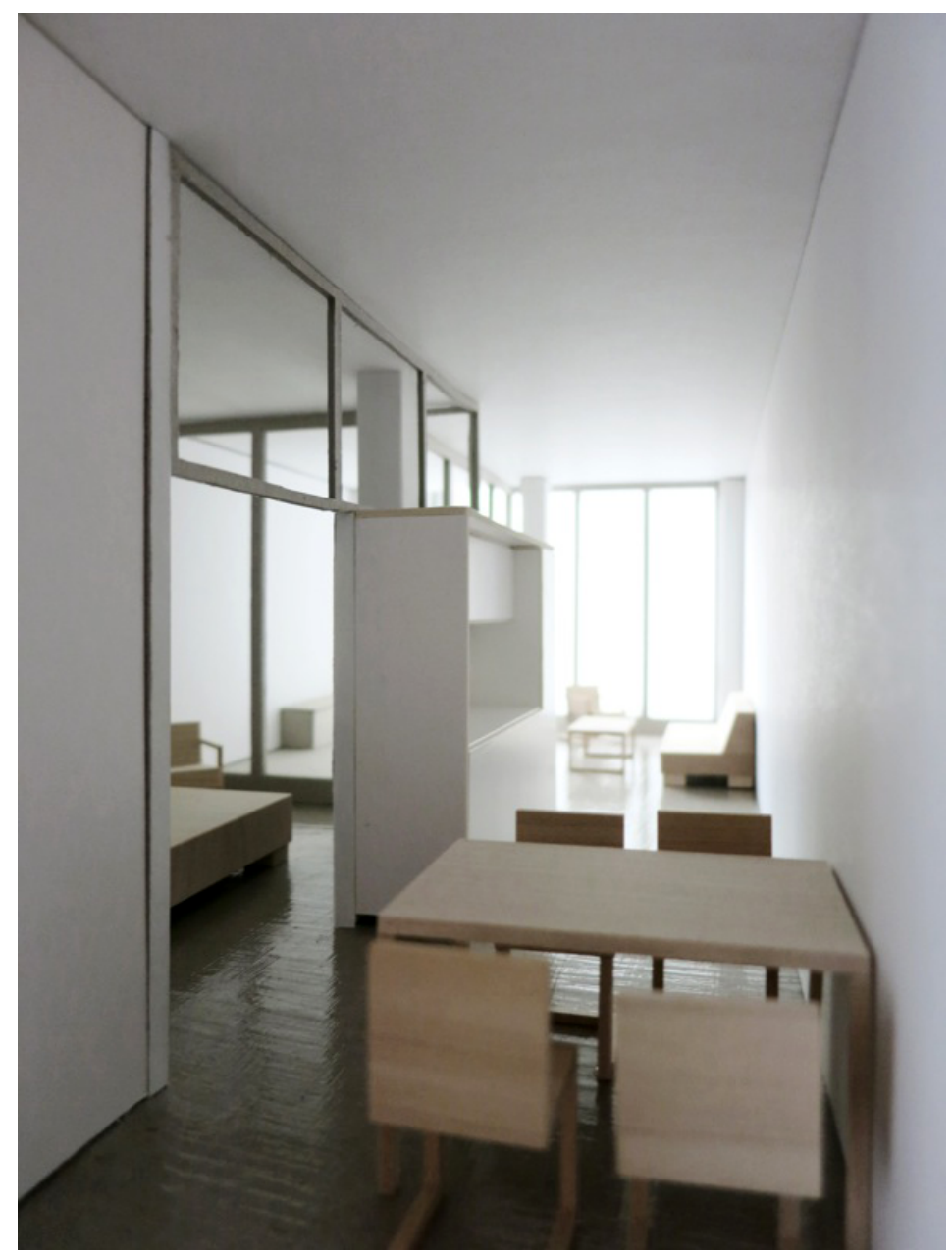

Figure 7. EMI Architekten, type MIN 1 of the Glattpark building (2013-2016), Opfikon, architectural model of the interior space. Image courtesy of EMI Architekten.

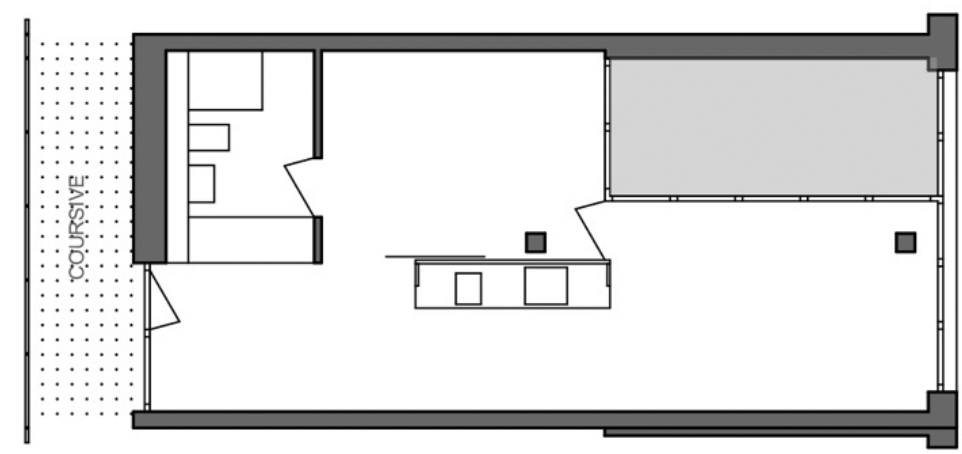

Figure 8. EMI Architekten, type MIN 1 of the Glattpark building (2013-2016), Opfikon, plan. Re-drawn by EPFL students for UE $B$ architectural critic course. 


\section{COGITATIO}

In Switzerland, the quest for maximum use of limited space also informs the MOVEment module by Halter (Figures 9 to 11). Its philosophy, as Terence Coran puts it, is that "plans for small units require a different approach compared to the ones used in large ones. Instead of associating each function to a space, each part of the unit has to be organized in the most flexible way possible" (as cited in Inauen, 2017, Franzinetti's translation).

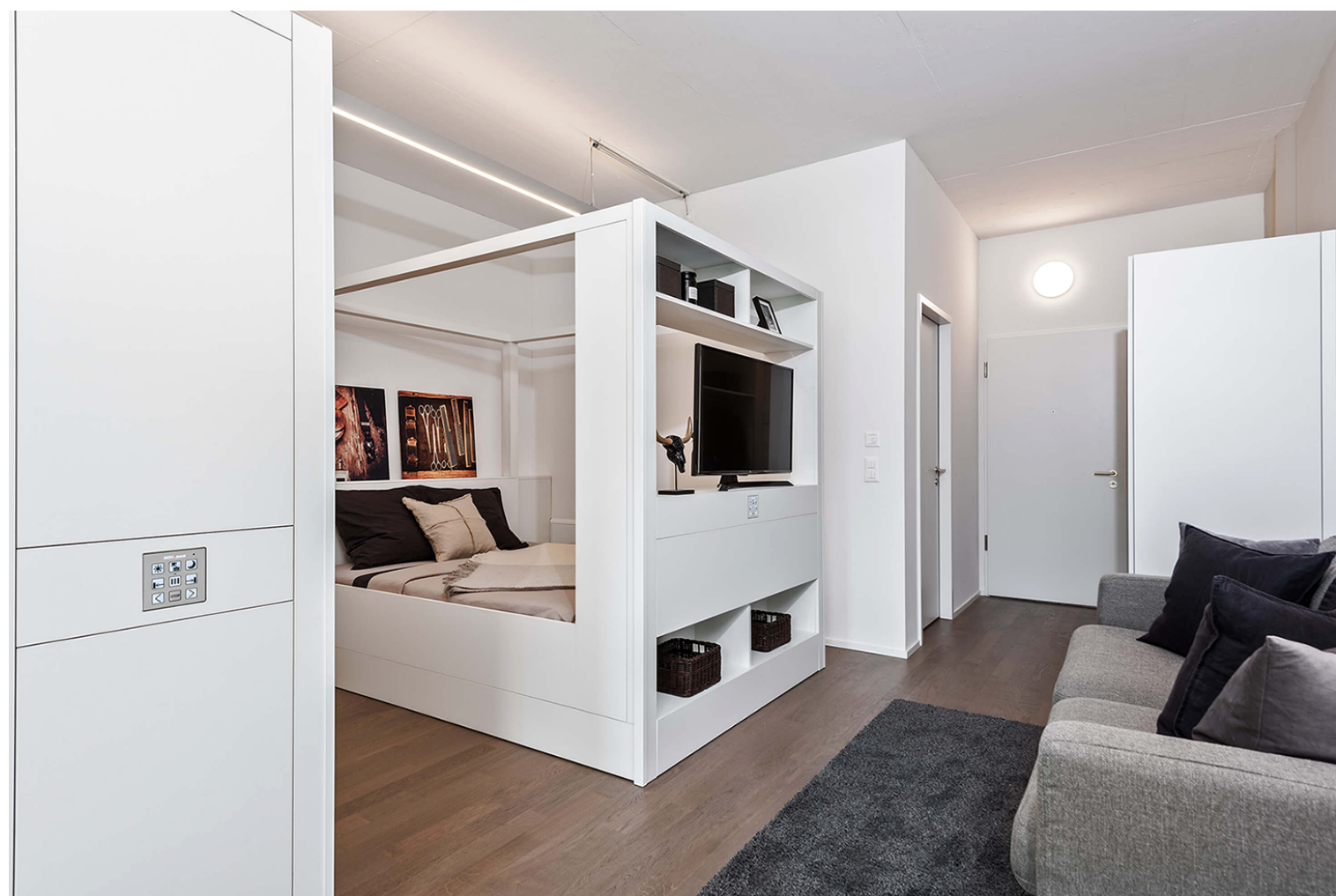

Figure 9. Halter, flexible MOVEment system, removable furniture in the living room-bedroom. Image courtesy of Halter.

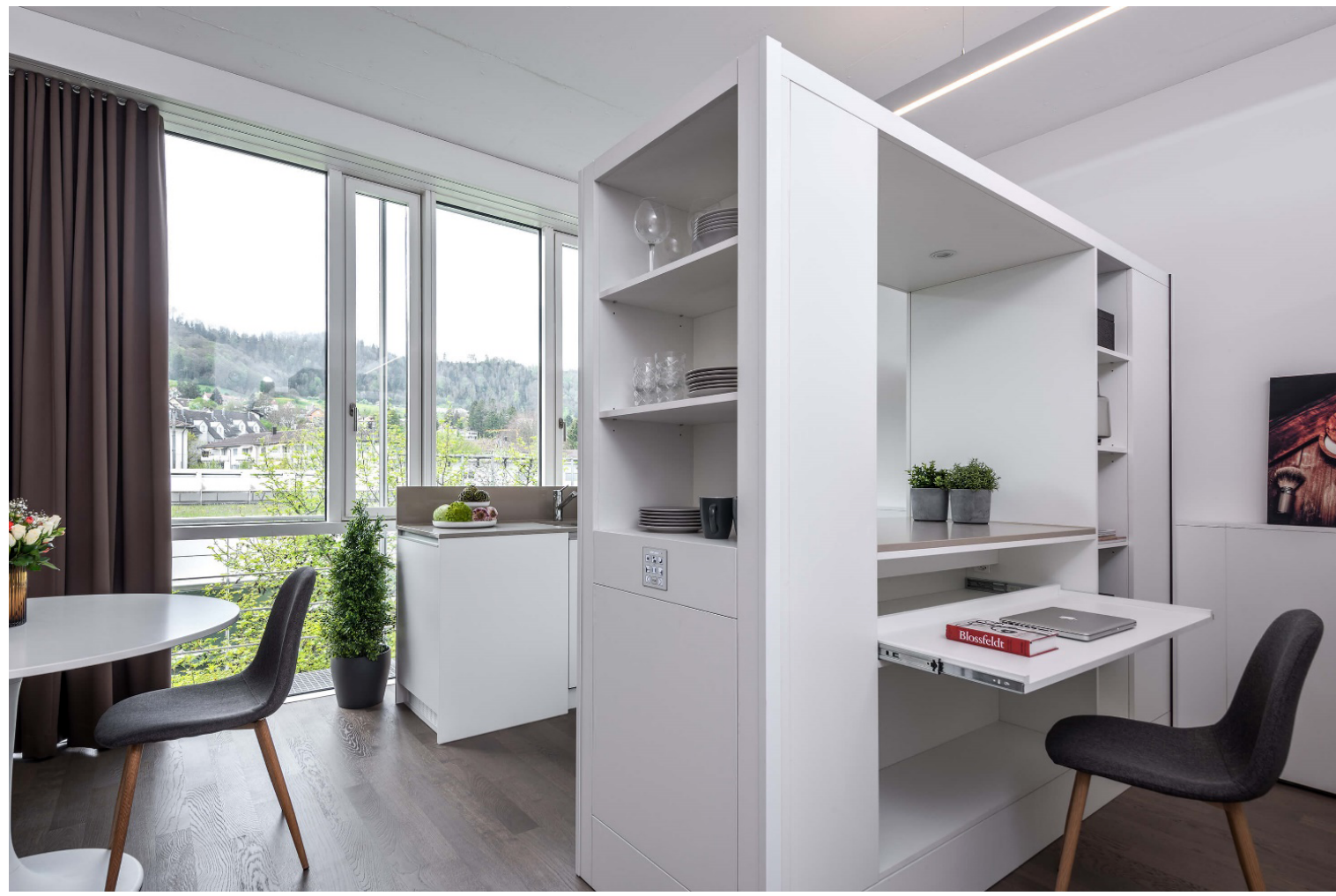

Figure 10. Halter, flexible MOVEment system, removable furniture in the living room-kitchen. Image courtesy of Halter. 

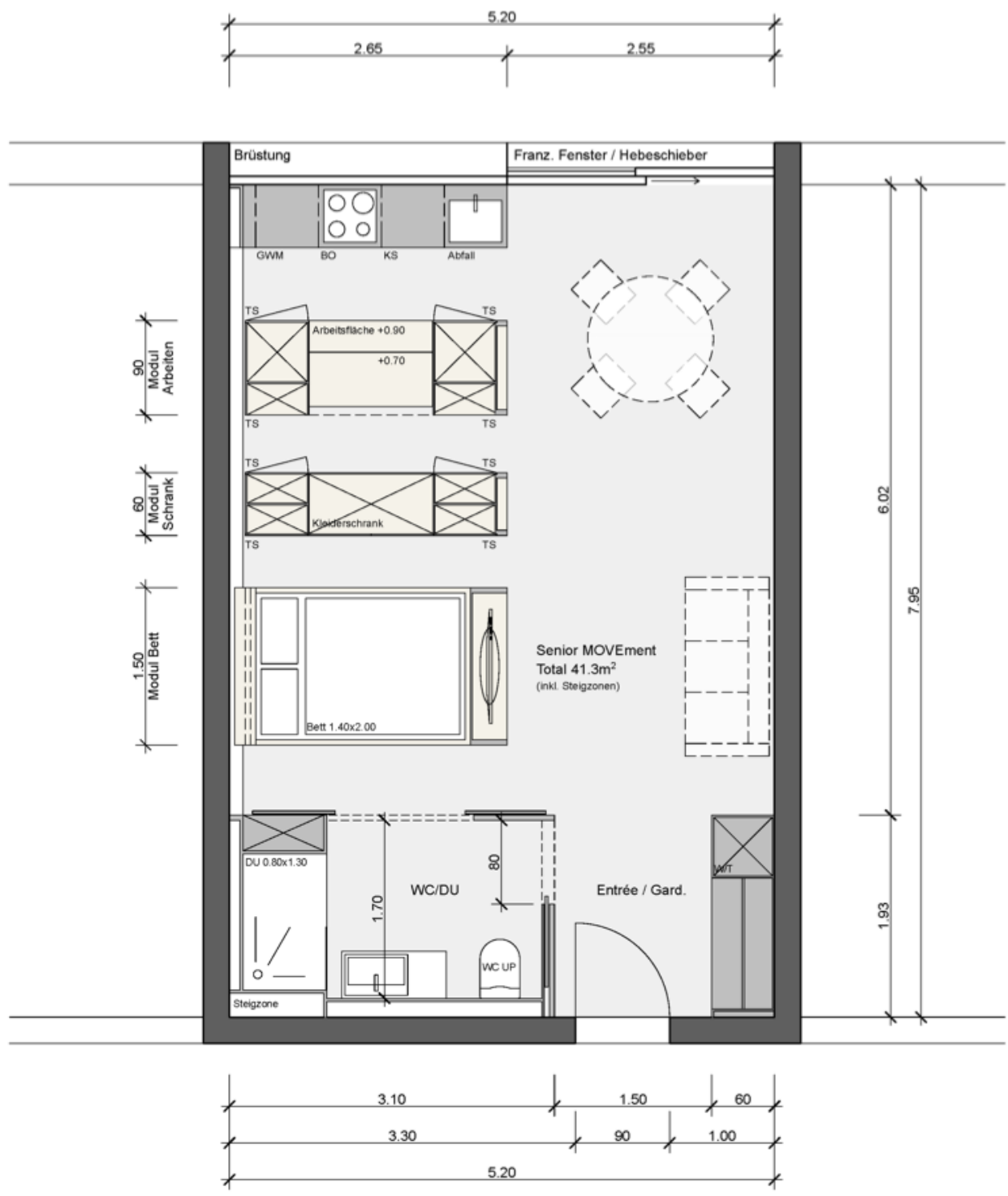

Figure 11. Halter, flexible MOVEment system, plan of the main type. Image courtesy of Halter.

The system is based on specific modules for beds, cupboards and a working area, framed by the bathroom, adjoining the entrance, while the kitchen furniture is located on the front. The water accesses are fixed, the other modules are mobile and according to their location; space layout varies, according to need, $32 \mathrm{sqm}$ for young people and 42 sqm for senior citizens.

There are two ways of approaching the idea of minimum housing: EMI's work, which is essentially architectural, based on exploiting the spatial development of housing with compact surfaces, that is establishing diagonal views. This was one of Wright's themes-the continuity of horizontal planes and the high height of the livable area/volume. Minimum surfaces, maximum architectural quality. The other is Halter's view without any great architectural expectation, returning to the theme of flexibility and spaces that can be reconverted by using removable furniture: Gene Kelly's dance scene continues, crisscrossing time.

\section{Acknowledgments}

I thank Victoria Franzinetti for the translation of the commentary into English.

\section{Conflict of Interests}

The author declares no conflict of interests.

\section{References}

Borngraeber, C. (1978). Les prétentions sociales de la Nouvelle Architecture et leur échec dans le nouveau Francfort [The social aims of New Architecture and their failure in the New Frankfurt]. In MNAM, CCI, BPI, \& IRCAM (Eds.), Paris-Berlin, 1900-1933, rapports et contrastes France-Allemagne: Art, architecture, graphisme, littérature, objets industriels, cinéma, théâtre, musique [Paris-Berlin, 1900-1933, 
France-Germany relationships and contrasts: Art, architecture, graphics, literature, industrial objects, cinema, theatre, and music] (pp. 373-379). Paris: Centre Georges Pompidou.

Frederick, C. (1915). Household engineering: Scientific management in the home. Chicago, IL: American School of Home Economics.

Freed, A. (Producer), \& Minnelli, V. (Director). (1951). An American in Paris [Motion Picture]. USA: MetroGoldwyn-Mayer.

Gropius, W. (1995). Fondements sociologiques de l'habitation minimale pour la population industrielle des villes (1929) [Sociological foundations of the minimum dwelling for the workers in the cities (1929)]. In W. Gropius (Ed.), Architecture et société [Architecture and society]. Paris: Éditions du Linteau.

Inauen, N. (2017). Halter's MOVEment [PowerPoint slides].

Le Corbusier Pierre Jeanneret. (1927). Zwei Wohnhäuser [Two houses]. Stuttgart: Dr. Fr. Wedekind \& Co.

Le Corbusier. (1928). La signification de la cité-jardin du Weissenhof à Stuttgart [The meaning of Weissenhof garden city in Stuttgart]. L'Architecture Vivante, 1928(19), 9-15.

Le Corbusier., \& Jeanneret, P. (1964). L'œuvre complète 1910-1929 [Complete works 1910-1929]. Zurich: Les Éditions d'Architecture.

May, E. (1930). La politique de l'habitation à Francfortsur-le-Mein [Dwelling policies in Frankfurt am Main]. L'architecte, 1930(1), 1-12.

Monnier, G. (1987). Automobile. In J. Lucan (Ed.), Le Corbusier: Une encyclopédie [Le Corbusier: An ency- clopaedia] Paris: Éditions du Centre Pompidou/CCI.

Move-ment. (n.d.). Gallery. Move-ment. Retrieved from https://move-ment.ch/en/\#gallery

Muller, J. (Ed.). (2005). Films des années 50 [Movies from 1950s]. Cologne: Taschen.

Murard, L., \& Zylberman, P. (1978). Esthétique du Taylorisme. L'habitat rationnel en Allemagne: De la stabilisation du mark à la stabilisation d'Hitler (1924-1933) [Aesthetics of Taylorism. Rational housing in Germany: From the stabilization of the Mark to Hitler's stabilization (1924-1933)]. In MNAM, CCI, BPI, \& IRCAM (Eds.), Paris-Berlin, 1900-1933, rapports et contrastes France-Allemagne: Art, architecture, graphisme, littérature, objets industriels, cinéma, théâtre, musique [Paris-Berlin, 1900-1933, France-Germany relationships and contrasts: Art, architecture, graphics, literature, industrial objects, cinema, theatre, and music] (pp. 384-390). Paris: Centre Georges Pompidou.

Quiring, C., Voigt, W., Cachola Schmal, P., \& Herrel, E. (Eds.). (2011). Ernst May 1886-1970. Munich, London and New York: Prestel.

Schütte-Lihotzky, M. (1927). Rationalisierung im Haushalt [The rationalization of housekeeping]. Das Neue Frankfurt, 1(5), 120-123.

Taut, B. (1924). Die neue Wohnung: Die Frau als Schöpferin [The new apartment: The woman as creator]. Leipzig: Klinkhardt.

Taylor, B. B. (1987). Loucheur [Squinter]. In J. Lucan (Ed.), Le Corbusier: Une encyclopédie [Le Corbusier: An encyclopaedia]. Paris: Éditions du Centre Pompi$\mathrm{dou} / \mathrm{CCl}$.

\section{About the Author}

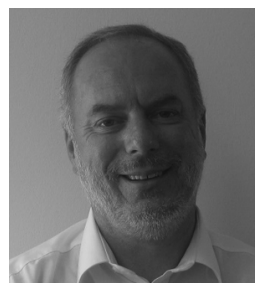

Bruno Marchand was born in 1955 and has Swiss nationality. He is an architect and graduated from the Ecole Polytechnique Fédérale de Lausanne (EPFL) in 1980 and was awarded a PhD in science in 1992. He has been Professor of Architectural Theory at the EPFL since 1997. He also chairs the Laboratory of Theory and History of Architecture 2 (LTH2) and the editorial board of matières-a review published by LTH2. He is currently independent and studies regional and urban design. 